\title{
Utilization of plants as dyes and natural color binder in Traditional Pringgasela Woven Fabric, East Lombok, West Nusa Tenggara, Indonesia
}

\author{
MULYATI RAHAYU, EMMA SRI KUNCARI", HIMMAH RUSTIAMI, DEWI SUSAN \\ Research Center for Biology, Indonesian Institute of Sciences. Cibinong Science Center, Jl. Raya Jakarta-Bogor Km. 46, Cibinong, \\ Bogor 16911, West Java, Indonesia. Tel./fax.: +62-21-8765066, ^email: emmakuncari@ gmail.com
}

Manuscript received: 7 February 2019. Revision accepted: 20 January 2020.

\begin{abstract}
Rahayu M, Kuncari ES, Rustiami H, Susan D. 2020. Utilization of plants as dyes and natural color binder in traditional Pringgasela woven fabric, East Lombok, West Nusa Tenggara, Indonesia. Biodiversitas 21: 636-641. Since earlier times, dye has an important role in human life, especially related to the ritual practice. Mineral material was first used as natural dyes. In order to inventory the uses of plants as a dye and natural color binder by the local community of Pringgasela, ethnobotany research was done. This research had been done by interviewing the "penyisik" of traditional woven fabric craftsmen and direct observation in the field. The results showed 13 plant species used as a dye and nine species as color binder. Parts of less utilized plants were used. It is hoped that this research can prevent synthetic dyes that have been circulating widely, which has a potential hazard and cause environmental pollution.
\end{abstract}

Keywords: Color binder, Lombok, natural dyes, Pringgasela, traditional weaving

\section{INTRODUCTION}

The demand for traditional Indonesian weaving is rising, along with the increasing need for exports and domestic consumption. In rural areas of Indonesia, many local people producing various traditional weaving patterns. Generally, traditional weaving enthusiasts prefer natural dyes. According to local people information, fabric dyes are classified into two, i.e.: (i) Natural Dyes, derived from natural ingredients either from plant or animal extraction; (ii) Artificial Dyes, synthetic dyes made by chemical reactions using basic materials such as tar, charcoal, coal or petroleum which are aromatic hydrocarbon derivatives such as benzene, naphthalene, and anthracene. Nowadays, artificial dye dominates the Indonesian market, due to a large number of colors, practical, easy to use and not easily fade (Isminingsih 1978). However, the use of natural dyes is in great demand because it produces beautiful, distinctive, and exclusive colors and cannot be imitated by synthetic dyes.

The use of synthetic dyes that are used in the process of coloring textile materials has caused many environmental problems because some synthetic dyes contain heavy metal pollutants. The heavy metals include $\mathrm{Cu}, \mathrm{Ni}, \mathrm{Cr}, \mathrm{Hg}$ and $\mathrm{Co}$ (Sugiyana 2003). These pollutants will eventually be wasted around the general public and polluting the environment, specifically aquatic environment (Wagner 2003). Since August 1, 1996, developed countries like Germany and the Netherlands have banned the use of chemical dyes. This prohibition refers to CBI (Center for the promotion of imports from developing countries) Ref, CBI/NB-3032 June 13, 1996, concerning coloring agent for clothing, footwear, bed linen should not use dyes that contain chemicals, but the dyes which do not have side effects on the environment and health namely natural dyes (Kwartiningsih 2009).

Since earlier times, color plays an important role in human life. Body painting has become part of the ritual process relating to the conduct of warfare or burial ceremonies thousands of years ago. Notes on the use of "tarum" (Indigofera spp.) were found as a fabric dye and household appliance more than 6,000 years ago in China. Whereas in Egypt 4,000 years old fabric was found and has been colored red, yellow, and green. Natural dyes originally came from minerals, but nowadays more come from plants. The increasing uses of natural dyes occurred in the $19^{\text {th }}$ century, but at the end of the century, most of the natural dyes were replaced by synthetic dyes. Most natural colors can be obtained from plant products. In plant tissue, there are different plant pigments that have different colors depending on their chemical structure. The plant pigment group can be in the form of chlorophyll, carotenoids, flavonoid, and quinone (Lemmens and Wulijarni-Soetjipto 1990).

The traditional cloth of the archipelago is a cultural heritage of various regions in Indonesia that must be preserved. There are several traditional fabrics of the archipelago that have meaning in each motif and color, including songket cloth, batik cloth, tapis cloth, gringsing cloth and ikat cloth (Mahadewi MCAAB 2015).

Through the traditional fabric works, we can see the results of cultural heritage reflecting customs owned by each region. One community group which passed down the weaving culture in Indonesia especially on the island of Lombok is the Sasak Tribe. The Sasak tribe has a population of approximately $90 \%$ of the whole population 
of Lombok. Other groups, such as tribes Bali, Sumbawa, Java, Arabic, and China are migrant groups on the island of Lombok (Budiwanti 2000).

There are several weaving centers in Lombok, one of them is Pringgasela Village located in East Lombok. Their weave designs are simple and full of meaning, stripes with a few decorative motifs that are inspired by the village surroundings. Various types of motifs are symbols of cultural information sources. Overall, it is an embodiment of the development of the craftsmen's mindset and artistic inspiration (Rupa 2017).

One of the efforts to reinstate the use of natural dyes for fabrics is to explore the abundant natural dyes in Indonesian archipelagoes. Ethnobotany research will inventory the diversity of plant species that are used as dyes and natural color binders in Pringgasela traditional weaving, East Lombok. Hopefully, the results of this study can enrich the plant species as source of natural dyes (including availability and variety of colors), preserve local wisdom and culture and also prevent the wider extent of environmental pollution because of the use of artificial dyes.

\section{MATERIALS AND METHODS}

Ethnobotany research on dyes and natural color binders on traditional Pringgasela weaved was done by interviewing and direct observation in the field. Pringgasela is one of the villages in Pringgasela Sub-district, East Lombok Regency, West Nusa Tenggara, Indonesia. The majority of the population are from the Sasak ethnic group (native ethnic Lombok Island), and are Muslim. The total population in 2017 was 24,752 (male) and 28,803 (female) (BPS East Lombok 2018). Pringgasela village has been known to the national level as one of the cultural villages with traditional woven production which is done conventionally. The main livelihood in the agricultural, plantation and fisheries sectors (men) and "penyisik" traditional weavers (women). Generally for women, after completing household work (washing, cooking, and cleaning the house), they will do activities related to weaving. They realize that woven fabric is a promising source for their income. Interviews were carried out on "Lalu" traditional leaders and "penyisik" of woven craftsmen who knew and used plant species as coloring fabric and woven colors.

Ethnobotany research data collection was carried out by referring to Sumingiat (2005) and Nolan and Turner (2011) with modifications namely non-structured and open-ended interviews and direct field observations. Interviews are addressed to traditional leaders known by the local community as "lalu" (1 person) and "penyisik" (6 people). Data of plant species that are used as dyes and natural color binders, such as local names, parts used, methods of processing, uses, colors produced and how to obtain them were recorded. Plants species that is scientifically not known yet was taken in the form of a herbarium specimen with reference to Nesbit (2014). Herbarium specimens were then identified at Herbarium Bogoriense, Research
Center for Biology, Indonesian Institute of Sciences (LIPI), Bogor, Indonesia. As a supporting data, literature searches related to natural dyes are also carried out.

\section{RESULTS AND DISCUSSION}

The use of plants as natural coloring agents can be obtained by fermentation, boiled or chemically. Field observation revealed that Pringgasela traditional weaving craftsmen got natural pigments by boiling parts of plants containing coloring compounds for 10-15 days and then allowed to stand for several days. The boiling was done traditionally using firewood.

The results of interviews and field observations revealed that more or less 13 plant species have been used as coloring woven fabric and nine plants as color binder by traditional weaving craftsmen in Pringgasela (Table 1). The results of ethnobotany research on Dani people in the Baliem, Irian Jaya valley conducted by Purwanto and Walujo (1992) recorded four plants used as coloring materials, while research on the Dawan community, on Timor Island, carried out by Walujo (1992) found six plants that are used as coloring agents and one plant as binder or color enhancer. Rifai and Walujo (1992) said that Madura community was using more or less 50 plant species to color typical batik of Madura, although not all plants were found in Madura, so since long time ago, they have been imported. Furthermore, Saefudin et al. (2018) recorded 71 plants species and 56 coloring pigmentproducing microorganisms. It seems that the use of tarum leaves (Indigofera tinctoria), turmeric rhizome (Curcuma longa) and noni roots (Moringa citrifolia) as natural coloring ingredients has been commonly used by weaving and batik craftsmen in Indonesia.

Pinang (Areca catechu) is a plant that is widely spread in various regions in Indonesia. In some Asian countries such as Indonesia, Malaysia, and India, pinang is used as one of ingredients of "sirih pinang", traditional medicine and appetizers (Brotonegoro et al. 2000). Fine grounded of old pinang is used as natural dyes by batik artisans in Burma, Malaysia, India, Philippines and New Guinea (Farnworth 1976). The diversity of Pinang species is quite common in Indonesia, and is planted as an ornamental plant in city, office, hotel, parks, roadside, and yards. Often old fruits were fallen around the tree without being used. Further research needs to be done to determine the highest tannin content in various pinang.

From the beginning to the end of the $19^{\text {th }}$ century, sepang wood was the main source of red to brownish coloring. However, its use as a coloring agent is only on a small scale. This is because the colors produced by synthetic dyes are brighter, do not fade quickly, the coloring process is easier, and production costs are cheaper. In India, Indonesia and the Philippines, sepang wood is also used as a traditional medicinal ingredient (Zerrudo 1985). It seems that the prospect as a medicinal plant is better than as a natural coloring agent. 

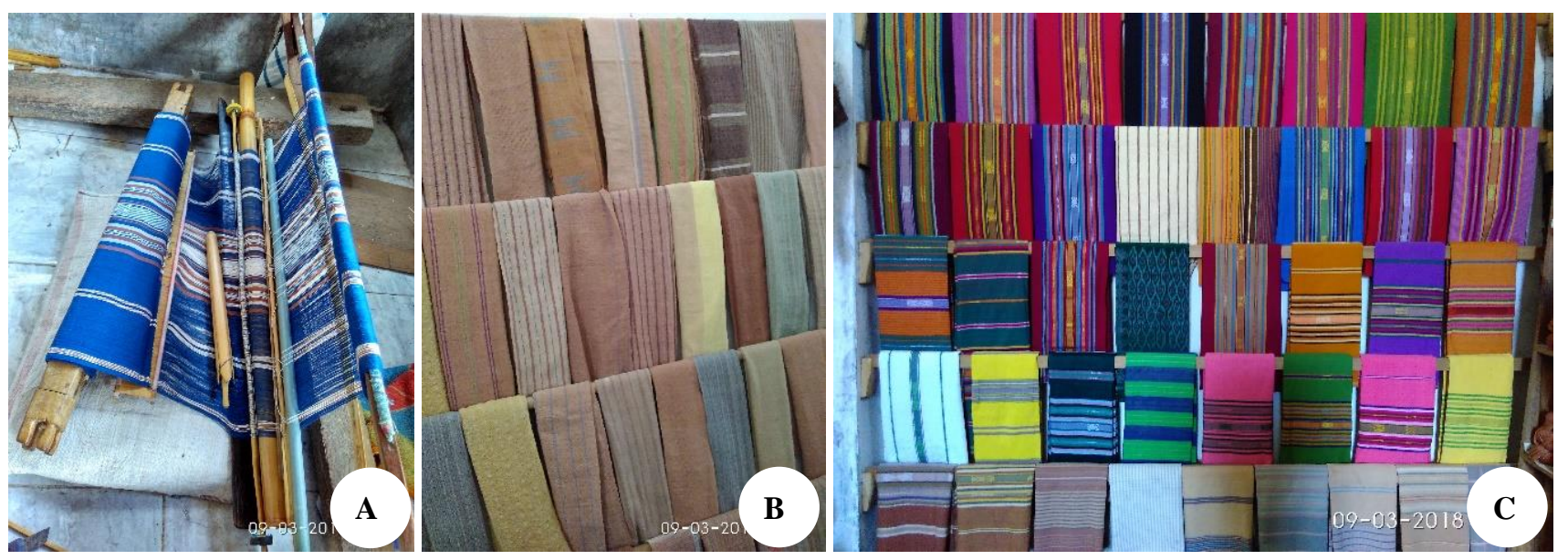

Figure 1. A. Woven fabric with "tarum" coloring base; B. Woven fabric with many natural dyes coloring base; C. Woven fabric with artificial coloring base

Table 1. List of plants used as dyes and natural color binder weaving fabric in Pringgasela, East Lombok, West Nusa Tenggara, Indonesia

\begin{tabular}{|c|c|c|c|}
\hline Scientific name & Local name & $\begin{array}{l}\text { Part of plant } \\
\text { used }\end{array}$ & Notes \\
\hline Anacardium occidentale L. & Mete & Seed skin & Color binder \\
\hline Areca catechu L. & Pinang & Seed & Color binder \\
\hline \multirow[t]{2}{*}{ Artocarpus heterophyllus Lam. } & Nangka bubur & Bark & Yellow brownish color \\
\hline & & Fruit straw & Color binder \\
\hline Caesalpinia sappan $\mathrm{L}$. & Sepang & Stem & Brown reddish color \\
\hline Calotropis gigantea (L.) Dryand. & Widuri/ biduri & Flower/leaf sap & Color binder \\
\hline Cocos nucifera $\mathrm{L}$. & Nyiur & Coconut fibre & Color binder \\
\hline Curcuma longa $\mathrm{L}$. & Kunyit & Rhizome & Yellow brownish color \\
\hline Garcinia $x$ mangostana $\mathrm{L}$. & Manggis & Fruit rind & Violet color \\
\hline Indigofera spp. & Tarum & Leaf & Blue color \\
\hline Lablab purpureus (L.) Sweet & Komak & Pod skin & Violet color \\
\hline Lannea coromandelica (Hout.) Merr. & Banten, kayu makasar & Bark & Chocolate color \\
\hline Lansium parasiticum (Osbeck) K.C. Sahni \& Bennet & Duku & Fruit skin & Color binder \\
\hline Mangifera spp. & Mangga & Bark, leaf & Color binder \\
\hline Morinda citrifolia $\mathrm{L}$. & Mengkudu & Root and old stem & Yellow color \\
\hline Musa spp. & Punti & Banana heart & Color binder \\
\hline Nephelium lappaceum L. & Rambutan & Fruit skin & Color binder \\
\hline Phaleria marcocarpa (Scheff.) Boerl. & Mahkota dewa & Fruit rind & Color binder \\
\hline Pterocarpus indicus Willd. & Angsana & Bark & Red color \\
\hline Pterospermum javanicum Jungh. & Bayur & Bark & Dark chocolate color \\
\hline Swietenia macrophylla King & Mahoni & Leaf & Chocolate color \\
\hline Tectona grandis L.f. & Jati & Leaf & Pale yellowish-brown color \\
\hline Terminalia catappa $\mathrm{L}$. & Ketapang & Leaf & Green color \\
\hline
\end{tabular}

Ketapang is a native plant of Southeast Asia; classified as one of the versatile tree species. In some Southeast Asian countries such as Thailand, the Philippines and Malaysia, their bark, leaves, and sometimes their roots and young fruit are used as tanners and give black color to cotton fabrics and rattan. However, its use as a coloring agent is limited, because of its tannin content is relatively low (Morton 1985). Traditional knowledge of local Pringgasela weavers does not use ketapang bark or roots as natural coloring agents, but only uses leaves decoction as green coloring. Leaves that are used as coloring agents are old leaves, even those that have fallen from the tree.

Kacapiring (Gardenia jasminoides) is pretty much planted as outdoors ornamental plants in Pringgasela. In China and Japan, the fruit flesh is used to coloring food and fabric. It gives yellow or dark red color (Freund et al. 1988). The knowledge of the use of fruit flesh for yellow coloring material is not owned by Pringgasela weavers. This is presumably because the fruit of Kacapiring has never been found in Pringgasela. In lieu of the yellow 
color, a decoction of teak leaves or turmeric rhizome is used, depending on the desired yellow color.

"Penyisik", notable person of traditional weaving craftsmen in Pringgasela, said that almost all plants can produce natural dies, but the most important thing is the binder or color enhancer. He said that plants bearing exudate (sticky or slimy) can be used as color binding material (Lalu Sareh 2018, pers. com.). Although not many plants are used as natural dyes, these plants are commonly found in Lombok, especially around Pringgasela. Most plant parts used are unutilized or wasted. Plant simplicia used as basic coloring materials are from two to three plant species to get a large amount of and different colors, such as mahogany bark boiled with tarum leaves will produce green color. This color is different from boiled ketapang leaves only. It is said by one of weaving craftsmen activities in Pringgasela that more than 50 colors can be produced by mixing many plant species. The viscosity of natural dyes, the length of dye weaving into the boiled water of coloring agents or color binders, the number of replications of dyeing, and the plant species used greatly affect the final color produced.

To obtain dyes with good fastness, it is necessary to do the fixation process. Fixation is a dyeing process that aims to lock the dyes that enter the fiber so that the resulting color not easy to fade (Amalia and Akhtamimi 2016). Another fixation function is to strengthen the color. According to Susanto (1973), there are two kinds of color binder/reinforcement namely natural and chemical reinforcement. Chemical binders such as chrome, copper, lead and iron; while the natural binder/reinforcement are citrus, lime, vinegar, alum, rock sugar, java sugar, lime water, tape, banana "klutuk" leaf, and guava leaf. So far the use of binder or color reinforcement is from chemical compounds such as tunjung $\left(\mathrm{FeSO}_{4}\right)$, alum $\left(\mathrm{Al}_{2}\left(\mathrm{SO}_{4}\right)_{3} .18 \mathrm{H}_{2} \mathrm{O}\right)$ and quicklime $\left(\mathrm{CaCO}_{3}\right)$ (Fitrihana 2007).

The information on the use of natural color binder needs to be followed up with related research. Because it can increase the value of these plant species and decreased environmental pollution because the use of chemical compounds can be minimized. The weavers are also happy to use natural materials because they are easy to obtain, do not buy, then the effect is also better for health, for example reducing hand itching and coughing pain due to the use of chemicals.

The use of rambutan fruit skin as a natural color binder and mangosteen rind as coloring material added the value of these plant species. Mangosteen, rambutan and durian fruit (Durio zibethinus) are the main fruits of Lombok Island, which are often referred to as "MaDuRa" (mangosteen, durian, rambutan). According to Wardi (2006) mangosteen, durian and rambutan are main three commodities of West Lombok's horticultural. These three commodities become attractive brands and superior varieties. The specialty of these three horticultural commodities lies in their sweet, legit taste and fragrant aroma that adds to the taste of fruit fans.

On the island of Lombok, there are three types of jackfruit, namely puree jackfruit, salak jackfruit, and superior jackfruit. Based on the quality of edible flesh, Soepadmo (1997) classified jackfruit trees into two groups, puree jackfruit, and salak jackfruit, whereas superior jackfruit is a new cultivar.

Jackfruit porridge name refers to the flesh that is thin, soft, somewhat fibrous, strong aroma, easily separated from the fruit; while salak jackfruit: thick fruit flesh, somewhat dry, less strong aroma (pig jackfruit and bones jackfruit) (Prihatman 2000).

From observations and interviews with the community in Pringgasela Village, the use of bark as coloring material and straw or pure jackfruit pulp fiber as a color binding material is one of the local knowledge of Sasak Pringgasela community in the utilization of low-quality fruit trees. Based on Rosyida and Zulfiya (2013) research result, jackfruit wood extract can be used to dye textile materials from natural fibers (cotton cloth) with yellow and brown colors. Jackfruit wood contains yellow coloring that called with morin (Lemmens dan Wulijarni-Soetjipto 1990). Morin is a derivative from flavon which is found in several Moraceae family (Emiliana et al. 2001).
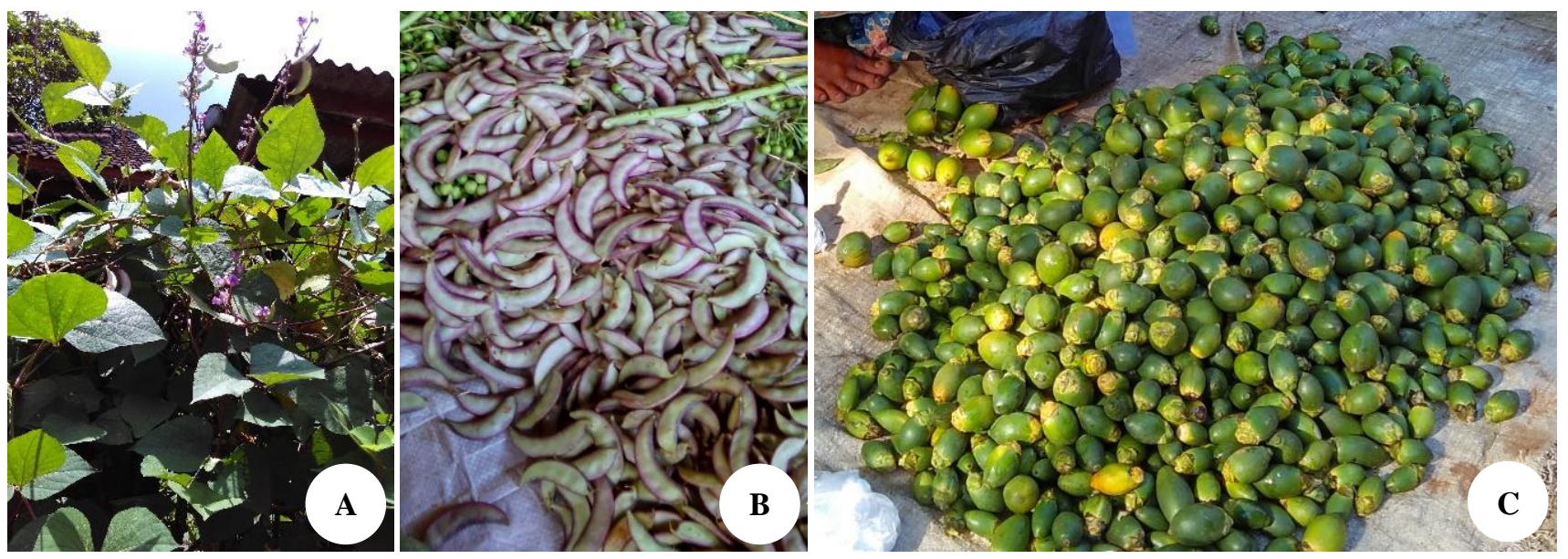

Figure 2. A. Komak tree; B. Komak fruit; C. Pinang fruit 

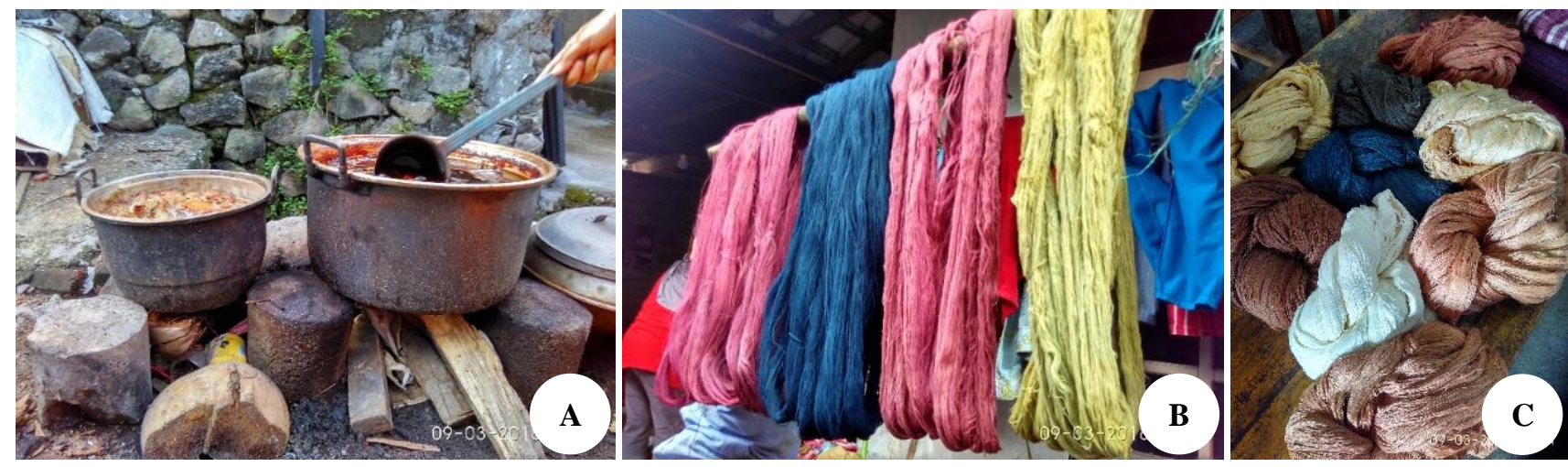

Figure 3. A. Boiling natural color binder (coconut fiber); B. Coloring yarn with mangosteen bark, tarum, and ketapang leaves; C. Weaving yarn with a variety of natural color

The final result of coloring depends on fixator used, while degree of coloring is determined by the $\mathrm{pH}$ (solution atmosphere) used in coloring, with the level of color aging as follows: $\mathrm{pH}$ alkali for the oldest colors, neutral $\mathrm{pH}$ for colors with moderate aging and acidic $\mathrm{pH}$ for the youngest color. Jackfruit wood can dye cotton fibers with yellow because jackfruit wood contains tannin "morin", which can give yellow citron. Morin can be extracted by using hot water. Yellow from morin can dye cotton permanently.

Six plants out of 13 coloring plants in Pringgasela are Caesalpinia sappan, Lablab purpureus, Lannea coromandelica, Pterospermum javanicum, Swietenia macrophylla, and Terminalia catappa; and seven species among nine species of binder or color enhancer are Artocarpus heterophyllus, Cocos nucifera, Lansium parasiticum, Mangifera spp., Musa spp., Nephelium lappaceum and Phaleria macrocarpa were not registered in the books of color-producing plants and tannins published by Plant Resources of South-East Asia (PROSEA) (Lemmens and Wulijarni-Soetjipto 1990).

In conclusion, the study of Pringgasela traditional weaving colors recognized 13 plant species used as dyes and nine species as binders. Parts of plants used are not (less) utilized. From the above discussion, shows local wisdom and local knowledge of Sasak Pringgasela community in utilizing the surrounding plants. Its utilization is not only for the economic needs of increasing family income, but also can minimize environmental pollution. Inventory of coloring plants and binders or color enhancers in Pringgasela traditional weaving, especially those not registered in Lemmens and Wulijarni-Soetjipto (1990) need to be followed up and preserved.

\section{ACKNOWLEDGEMENTS}

This research grant from DIPA (Daftar Isian Pelaksanaan Anggaran) Project 'Biota Diversity and its Potency in Nusa Tenggara'. We express our gratitude to Research Center for Biology, Indonesian Institute of Sciences, Bogor, Indonesia for financial support. We acknowledge Lalu Sareh Erwin and local people for important information.

\section{REFERENCES}

Amalia R, I Akhtamimi. 2016. Study on effect of fixation substance types and concentrations on the quality of batik color with natural dyeing from rambutan skin waste (Nephelium Lappaceum). Dinamika Kerajinan dan Batik 33 (2): 85-92. [Indonesian]

BPS East Lombok. 2018. Jumlah Penduduk Kabupaten Lombok Timur Menurut Jenis Kelamin Tahun 2010-2017. Badan Pusat Statistik (BPS), Lombok Timur. https://lomboktimurkab.bps.go.id/ dynamictable/2015/11/04/13/jumlah-penduduk-kabupaten-lomboktimur-menurut-jenis-kelamin-tahun-2010-2017.html [Indonesian]

Brotonegoro S, Wessel M, Brink M. 2000. Areca catechu L. In: van der Vessen HAM, Wessel M (eds.) Plant Resources of South-East Asia No. 16. Stimulants. PROSEA Network Office. Bogor Indonesia.

Budiwanti E. 2000. Islam Sasak: Wetu Telu Versus Waktu Lima. PT LKiS Pelangi Aksara, Yogyakarta. [Indonesian]

Emiliana K, Widhiati, Kuwatno. 2001. Penggunaan Ekstrak Kayu Nangka (Artocarpus heterophyllus) sebagai Bahan Pewarna untuk Kulit. Majalah Barang Kulit, Karet dan Plastik 17 (1-2): 10-16. [Indonesian]

Farnworth FR. 1976. Betel Nut-Composition, Chemistry and Uses. Science in New Guinea 4 (2): 85-90.

Fitrihana N. 2007. Teknik Eksplorasi Zat Pewarna Alam dari Tanaman di Sekitar Kita untuk Pencelupan Bahan Tekstil. Jurusan PKK, Fakultas Teknik, Universitas Negeri Yogyakarta, Yogyakarta. [Indonesian]

Freund PR, CJ Washam, M Maggion. 1988. Natural color for use in food. Cereal Food Word 13 (7): 553-558.

Isminingsih. 1978. Pengantar Kimia Zat Warna. STTT, Bandung. [Indonesian]

Kwartiningsih E. 2009. Zat Warna Alami Tekstil. Ekuilibrium 8 (1): 4147. [Indonesian]

Mahadewi MCAAB. 2015. Klasifikasi Kain Tradisional Nusantara dengan Menggunakan Algoritma Naive Bayes Classifier. [Hon. Thesis]. Program Studi Teknik Informatika, Fakultas Sains dan Teknologi, Universitas Sanata Dharma, Yogyakarta. [Indonesian]

Morton JF. 1985. Indian almond (Terminalla catappa), salt-tolerant, useful, tropical tree with fruit worthy of improvement. Econ Bot 39 (2): 101-102.

Nesbitt M. 2014. Use of Herbarium Specimen in Ethnobotany. In: Salick J, Konchar K, Nesbitt M (eds). Curating Biocultural Collection: A Handbook. Royal Botanical Garden, Kew, UK.

Nolan JM, NJ Turner. 2011. Ethnobotany: The Study of People-Plant Relationship. In: Andersen EN, Pearsall D, Hunn E, Turner NJ (eds.). Ethnobotany. Wiley-Blackwell, New Jersey.

Prihatman K. 2000. Sistim Informasi Manajemen Pembangunan di Perdesaan, BAPPENAS. TTG Budidaya Pertanian. Kantor Deputi Menegristek Bidang Pendayagunaan dan Pemasyarakatan Ilmu Pengetahuan dan Teknologi, Jakarta. [Indonesian]

Purwanto Y, Waluyo EB. 1992. Etnobotani Suku Dani di Lembah BaliemIrian Jaya: Suatu Telaah Tentang Pengetahuan dan Pemanfaatan Sumber Daya Alam Tumbuhan. Prosiding Seminar dan Lokakarya Nasional Etnobotani 1. Cisarua-Bogor, 19-20 Februari 1992. Departemen Pendidikan dan Kebudayaan Republik Indonesia, 
Lembaga Ilmu Pengetahuan Indonesia dan Perpustakaan Nasional Republik Indonesia, Jakarta. [Indonesian]

Rifai MA, Waluyo EB. 1992. Etnobotani dan Pengembangan Tumbuhan Pewarna Indonesia: Ulasan Suatu Pengamatan di Madura. Prosiding Seminar dan Lokakarya Nasional Etnobotani 1. Cisarua-Bogor, 19-20 Februari 1992. Departemen Pendidikan dan Kebudayaan Republik Indonesia, Lembaga Ilmu Pengetahuan Indonesia dam Perpustakaan Nasional Republik Indonesia. [Indonesian]

Rosyida A, Zulfiya A. 2013. Pewarnaan bahan tekstil dengan menggunakan ekstrak kayu nangka dan teknik pewarnaannya untuk mendapatkan hasil yang optimal. Jurnal Rekayasa Proses 7 (2): 52-58. [Indonesian]

Rupa IW. 2017. Kain Tenun Pringgasela Kabupaten Lombok Timur Provinsi Nusa Tenggara Barat. Balai Pelestarian Nilai Budaya Bali, Denpasar. [Indonesian]

Saefudin, Basri E, Santoso A, 2018. Bahan Alam Pewarna Batik dan Tenun. Forda Press. Bogor. [Indonesian]

Soepadmo E. 1997. Artocarpus heterophyllus Lamk dalam: Buah-buahan Yang Dapat Dimakan. Sumber Daya Nabati Asia Tenggara 2. Verheij EWM, Coronel RE (eds). PT Sun, Jakarta. [Indonesian]

Sugiyana D. 2003. Pencemaran Logam Berat pada Limbah Industri Tekstil dan Alternatif Material Penyerap Ekonomis. Arena Tekstil 39. Balai Besar Tekstil. Bandung. [Indonesian]
Sumingiat VJ. 2005. Ethnobotanical Documentation: A Use s Guide. Asia-Pacific Database on Intangible Cultural Heritage (ICH) by AsiaPacific Culture Centre for UNESCO, Paris.

Susanto S. 1973. Seni Kerajinan Batik Indonesia, BPKB, Yogyakarta. [Indonesian]

Wagner S. 2003. Improvement in Product and Processing to Diminish Environmental Impact. COTTECH Conference Raleigh. North Carolina. November 2013.

Walujo EB. 1992. Tumbuhan dalam Kehidupan Masyarakat Dawan di Pulau Timor. Prosiding Seminar dan Lokakarya Nasional Etnobotani 1. Cisarua-Bogor, 19-20 Februari 1992. Departemen Pendidikan dan Kebudayaan Republik Indonesia, Lembaga Ilmu Pengetahuan Indonesia dan Perpustakaan Nasional Republik Indonesia, Jakarta. [Indonesian]

Wardi. 2016. Usaha Bibit Buah di Lingsar, Laris Manis Hingga Istana Presiden. http://lombokbaratkab.go.id/usaha-bibit-buah-di-lingsarlaris-manis-hingga-istana-presiden/ [Indonesian]

Zerrudo JV. 1985 Sebukao (Caesalpinia sappan L.) a Multipurpose Tree. Diamond Jubilee Professorial Lecture. University of the Philippina at Los Banos College, Laguna, Philippines.

Lemmens RHMJ, Wulijarni-Soetjipto N. 1990. Plant Resources of SouthEast Asia, Volume 3: Dye and Tannin-Producing Plants. Pudoc, Wageningen, Nederlands. 